OPEN ACCESS

Edited by:

Robert H. Mak,

University of California, San Diego,

United States

Reviewed by:

Kimberly Jean Reidy,

Montefiore Medical Center

United States

Wai Cheung,

University of California, San Diego,

United States

*Correspondence:

Adrian S. Woolf

adrian.woolf@manchester.ac.uk

Specialty section:

This article was submitted to

Pediatric Nephrology,

a section of the journal

Frontiers in Pediatrics

Received: 02 December 2018 Accepted: 22 March 2019

Published: 11 April 2019

Citation:

Woolf AS, Lopes FM, Ranjzad P and

Roberts NA (2019) Congenital

Disorders of the Human Urinary Tract:

Recent Insights From Genetic and

Molecular Studies.

Front. Pediatr. 7:136

doi: 10.3389/fped.2019.00136

\section{Congenital Disorders of the Human Urinary Tract: Recent Insights From Genetic and Molecular Studies}

\author{
Adrian S. Woolf ${ }^{1,2 *}$, Filipa M. Lopes ${ }^{1}$, Parisa Ranjzad ${ }^{1}$ and Neil A. Roberts ${ }^{1}$ \\ ${ }^{1}$ Division of Cell Matrix Biology and Regenerative Medicine, Faculty of Biology Medicine and Health, School of Biological \\ Sciences, University of Manchester, Manchester, United Kingdom, ${ }^{2}$ Royal Manchester Children's Hospital, Manchester \\ University NHS Foundation Trust, Manchester Academic Health Science Centre, Manchester, United Kingdom
}

The urinary tract comprises the renal pelvis, the ureter, the urinary bladder, and the urethra. The tract acts as a functional unit, first propelling urine from the kidney to the bladder, then storing it at low pressure inside the bladder which intermittently and completely voids urine through the urethra. Congenital diseases of these structures can lead to a range of diseases sometimes associated with fetal losses or kidney failure in childhood and later in life. In some of these disorders, parts of the urinary tract are severely malformed. In other cases, the organs appear grossly intact yet they have functional deficits that compromise health. Human studies are beginning to indicate monogenic causes for some of these diseases. Here, the implicated genes can encode smooth muscle, neural or urothelial molecules, or transcription factors that regulate their expression. Furthermore, certain animal models are informative about how such molecules control the development and functional differentiation of the urinary tract. In future, novel therapies, including those based on gene transfer and stem cell technologies, may be used to treat these diseases to complement conventional pharmacological and surgical clinical therapies.

Keywords: bladder, hydronephrosis, posterior urethral valves, prune belly syndrome, urofacial syndrome, ureter, vesicoureteric reflux

\section{INTRODUCTION}

The urinary tract comprises the renal pelvis, the ureter, the urinary bladder and the urethra. The tract acts as a functional unit, first propelling urine from the kidney to the bladder, then storing it at low pressure inside the bladder which intermittently and completely voids urine through the urethra. In fact, it was the anatomist Andreas Vesalius who five centuries ago based on his careful autopsy studies (1) reasoned that the kidney, ureter and bladder form a single functional unit. Prior to this, authorities surmised that the kidneys somehow cleaned the blood but they did not necessarily appreciate their anatomical connection with the lower urinary tract.

Congenital diseases of the urinary tract can lead to a range of devastating diseases sometimes associated with fetal losses or kidney failure in childhood and later in life (2-4). In some of these disorders, parts of the urinary tract are absent, while in other cases the organs are present but are severely malformed. In yet other cases, the organs appear grossly intact yet they have congenital functional deficits that can compromise health. Human studies are beginning to indicate monogenic causes for some of these diseases, as reviewed in the last decade (5). Here, we present an update of several of the implicated genes which encode smooth muscle, neural or urothelial 
structural, and functional molecules, or master transcription factors that regulate their expression. Furthermore, certain animal models are informative about how such molecules control the development and functional differentiation of the urinary tract, and we have alluded to several of them here.

This review does not focus on the detailed anatomy and developmental biology of the kidney and urinary tract, and for reviews of these aspects the reader is referred to other literature (6-8). Furthermore, our focus on the urinary tract does not cover the genetic bases of human kidney malformations per se and for this specific topic the reader is directed to other reviews $(3,9,10)$. Lastly, although the term 'congenital anomalies of the kidney and urinary tract', or CAKUT, might be used to include some of the entities we discuss here, we have elected not to use this term because its all-encompassing remit lacks the focus that is required here on the ureter and bladder. Finally, it is important to recognize that factors that perturb embryonic milieu may also adversely impact on urinary tract development: these include maternal diet, vitamin availability, levels of blood glucose and in vitro fertilization: again, these aspects are considered elsewhere (11-14).

Table 1 lists the prevalence of several of the congenital urinary tract diseases that will be discussed, and Table 2 list some of the genes implicated in their pathogenesis.

\section{GENETIC STUDIES OF VESICOURETERIC REFLUX, A COMMON URINARY TRACT MALFORMATION}

Certain types of urinary tract malformation are thought to be common, such as primary non-syndromic vesicoureteric reflux (VUR). The term describes the retrograde trajectory of urine from the bladder into the upper urinary tract that is neither caused by bladder outflow obstruction (i.e., "primary") nor associated with malformations outside the renal tract (i.e., "non-syndromic"). The precise prevalence of this condition is uncertain because large asymptomatic populations have not been screened by cystography. The prevalence, however, has been estimated to be as high as $10 \%$ percent in babies and young children (18). Prospective studies have shown that milder degrees of VUR usually spontaneously regress during childhood (24).

TABLE 1 | Prevalences of human congenital urinary tract diseases.

\begin{tabular}{llc}
\hline Urinary tract disease & Prevalence & References \\
\hline Bladder exstrophy & $0.002 \%$ births & $(15)$ \\
Megabladder & $0.30-0.06 \%$ in first trimester & $(16)$ \\
Posterior urethral valves & $0.01 \%$ births \\
Primary non-syndromic & Estimated 1-10\% in young \\
vesicoureteric reflux & children \\
Prune belly syndrome & 0.004\% live births \\
Ureteropelvic junction & Up to 0.4\% of newborns \\
obstruction & & \\
Urofacial syndrome & Prevalence unknown but around \\
& 150 & postnatal cases reported
\end{tabular}

Families with multiple members affected by VUR are recognized yet may not have been exhaustively investigated by cystography. This makes it challenging to track VUR within families. All these aspects make it challenging to undertake genetic studies in primary VUR. Indeed, numerous studies have undertaken genetic linkage or association analyses and indicated various loci as candidates for primary VUR (25-30). Unfortunately, there has been little inter-study uniformity in the loci. Reasons could be that the studies were underpowered, primary VUR is genetically heterogenous, and its modes of inheritance are varied. The largest published study to date (31), using parametric linkage analysis of 1,062 affected individuals from 460 families under a dominant model, identified a single region on chromosome 10q26. The locus contains 69 genes, yet sequencing them failed to reveal likely pathogenic variants in their coding regions. One explanation could be that the region contains mutations in yetto-be defined non-coding regulatory regions of genes that direct ureter development. Other studies have pointed to variants in specific genes. Two such studies $(32,33)$ implicated variants of $\mathrm{ROBO} 2$ in primary VUR, and mutations in this gene do cause ureter malformations in mice $(32,34)$. Others, however, were unable to confirm the observations in other primary VUR populations (35). A similar story of non-replication $(36,37)$ applies to variants in the gene called RET that encodes a growth factor receptor that drives growth of the embryonic ureter rudiment (38). The uroplakins are a family of proteins that form heterodimers that coat the apical surface of the urothelium that lines the renal pelvis, the ureter and the bladder (39). They are thought to confer water-proofing properties and so prevent the egress of urine back into the body. Mice with homozygous mutations of uroplakin IIIa (UpkIIIA) or UpkII

TABLE 2 | Genes implicated in congenital disorders of the human urinary tract.

ACTA2 encoding the smooth muscle contractile protein alpha smooth muscle actin

ACTG2 encoding the smooth muscle contractile protein $\gamma 2$-actin

BNC2 encoding basonuclin 2, a zinc finger containing protein implicated in epithelial maturation

CHRM3 encoding M3, the main acetylcholine receptor in detrusor smooth muscle

HNF1B encoding a transcription factor widely expressed in renal tract epithelia HPSE2 encoding heparanase 2, a protein that may modulate growth factor signaling in bladder nerves

ISL1 encoding a transcription factor that may be involved in formation of the bladder and urethra

LRIG2 encoding leucine-rich-repeats and immunoglobulin-like-domains 2 that may modulate growth factor signaling in bladder nerves

MYH11 encoding the smooth muscle contractile protein called myosin heavy chain 11

MYLK encoding myosin light chain kinase that modifies myosin in smooth muscle cells

PAX2 encoding a transcription factor widely expressed in the developing ureter and kidney

TBX18 encoding a transcription factor that affects morphogenesis of the ureter TNXB encoding an extracellular matrix protein found in the urinary tract TSHZ3 encoding a transcription factor that modulates smooth muscle differentiation

UPKIIIA encoding a member of the uroplakin family that water-proofs the urothelium 
have severe urinary tract malformations including VUR and hydronephrosis (39), and when the zebrafish homolog called upkIII was experimentally knocked-down, embryonic kidney tubule epithelia showed mislocalisation of proteins including the $\mathrm{Na}^{+} / \mathrm{K}^{+}$-ATPase (40). Rare individuals with heterozygous predicted pathogenic UPKIIIA mutations have been reported (41-43) and some have ureter malformations, including VUR. In contrast, when large populations with primary non-syndromic VUR were studied, UPK mutations could not be identified (44). One explanation could be that UPK mutations are rarely compatible with life and so would not be expected to be found in generally healthy individuals with VUR.

\section{GENETIC BREAKTHROUGHS IN SYNDROMIC CONGENITAL DISORDERS OF THE HUMAN URINARY TRACT}

If discovering specific genetic causes of primary non-syndromic VUR has so far proved elusive, much more progress has been made in defining causative genes in syndromic congenital disorders of the urinary tract i.e., those where there is associated disease outside the urinary tract. In this respect, perhaps the most convincing gene implicated thus far in human primary VUR is TNXB that encodes an extracellular matrix protein that is expressed in the urinary tract (45). A heterozygous variant was found to track with VUR in a large family, and cell biology experiments showed that the variant altered cell motility in cultured fibroblasts. Furthermore, rare TNBX missense variants were found in certain VUR families in another study (46). Close inspection of affected individuals revealed that some have joint hypermobility and, of note, TNBX loss of function mutations had previously been reported in Ehlers-Danlos syndrome (47). Thus, these families with VUR and TNXB variants might be considered to have a forme-fruste on the full-blown EhlersDanlos syndrome that has been reported to be associated with urinary bladder diverticula (48). Similar observations have been made for $P A X 2$, a gene that encodes a transcription factor which is widely expressed in the developing kidney and the urinary tract, and also the optic nerve. Mice with heterozygous mutations of Pax2 have congenitally small kidneys and can have VUR (49, 50). Rare individuals born with malformed kidneys, sometimes accompanied by VUR, have been found to carry heterozygous PAX2 mutations $(51,52)$. A subset of such individuals also have optic nerve malformations (51), so fulfilling all the criteria of the full-blown 'renal coloboma syndrome'. Again, however, when $P A X 2$ was sequenced in larger populations with primary non syndromic VUR, mutations could not be identified (53). In the remainder of this review, we will focus on several other rare diseases with defined genetic causes.

\section{PRUNE BELLY SYNDROME}

Prune belly syndrome describes a constellation of signs present from the antenatal period featuring a massively distended bladder that fails to empty fully, and overlying abdominal wall muscles that are thinner than normal (54). It nearly always occurs in boys when the signs include undescended testicles. For this condition, the term "sequence" may be more accurate than "syndrome" because the abdominal features could be secondary to the massive bladder distention. The prevalence of prune belly syndrome has been calculated as being 3.8 per 100,000 live births (19). Before birth, the syndrome is one cause of "megabladder," a massively dilated bladder, a phenotype with a first trimester prevalence of 1:330-1670 (16). From review of the detailed phenotypes $(55,56)$, prune belly syndrome is likely to have more than one etiology. On histology, some affected individuals have physical blockade of the urethra, for example with urethral agenesis or valves, with a hypertrophied bladder wall. Others, by contrast, have an overtly patent urethra, sometimes with a poorly developed prostatic bed and their bladders can contain disorganized muscle bundles and prominent connective tissue. These two categories would therefore, respectively have either "anatomic" or "functional" bladder obstruction. Contraction of detrusor smooth muscle in the body of the bladder is the driver for urinary voiding, and the neural signal to contract is acetylcholine that is released by parasympathetic autonomic nerves and which binds to the M3 muscarinic receptor. Homozygous, putative loss-of-function mutations, of $C H R M 3$ have been reported in a family with several males affected by a prune belly-like disease (57). CHRM3 codes for M3 and the large floppy bladders in this family strikingly resemble the phenotype reported in male homozygous Chrm3 mutant mice (58). M3 also mediates pupillary contraction to light and the above family showed defects in this reflex (57). A family with a phenotypically similar bladder and eye syndrome have been described but genetic tests were reported to be unrevealing (59). Of note, M3 is present in the embryonic bladder urothelium, as well as in smooth muscle, indicating that it may have other, as yet undefined, roles in the developing urinary tract (57).

Other individuals found to have massively dilated bladders yet no anatomical outflow obstruction carry mutations of genes that encode smooth muscle contractile proteins, or other molecules needed for their functionality. Indeed, mutations of the following genes have been identified in either prune belly or the overlapping disease called megacystis microcolon intestinal hypoperistalsis syndrome: ACTA2, encoding $\alpha$-smooth muscle actin (60); ACTG2, encoding $\gamma 2$ smooth muscle actin (61); MYH11, encoding a smooth muscle heavy chain protein (62); and MYLK encoding myosin light chain kinase that modifies myosin chains in smooth muscle cells (63). Another candidate gene in relation to myogenic failure is MYOCD that encodes a transcription-related protein needed for expression of smooth muscle contractile proteins (64-66). A study that used microarrays to seek copy number variants in 34 cases of prune belly syndrome found that one carried a deletion of a locus encompassing MYOCD (67). Finally, heterozygous whole gene deletions of $H N F 1 B$ have been reported in rare patients with prune belly syndrome (68). The gene codes for hepatocyte nuclear factor $1 \mathrm{~B}$ transcription factor that is widely expressed in epithelia in the developing renal tract (69). On the other hand, while heterozygous mutations of HNF1B are wellrecognized to cause diverse kidney malformation, these patients do not have prune belly syndrome (70). Moreover, another study found that, while a patient with prune belly syndrome carried a 
missense variant of $H N F 1 B$, this did not affect the transactivation functional of the encoded protein (71). A further caveat is that whole gene deletions of $H N F 1 B$ may also extend to adjacent genes (68) so that the final phenotype may not be ascribed to $H N F 1 B$ itself.

\section{UROFACIAL SYNDROME}

Urofacial, or Ochoa, syndrome (UFS) is characterized by a bladder in which the detrusor contracts against an incompletely dilated bladder outflow tract, with the result being high hydrostatic pressures within the bladder yet incomplete voiding (23). It is therefore another example of functional bladder outlet obstruction. Complications include high pressure VUR, ascending bacterial infection, pyelonephritis and renal failure. Affected individuals also have a characteristic grimace when smiling, and a neurogenic basis for this bladder disease has long been surmised (72). The prevalence of the syndrome is not known but at around 150 cases, mostly children, have been reported in the medical literature (23). Inherited in an autosomal dominant manner, a subset of affected families have biallelic mutations of HPSE2 (73-77) encoding a protein called heparanase 2 that inhibits the enzymatic activity of heparanase (78) that can release growth factors sequestered on matrix molecules called glycosaminoglycans. Other families with UFS instead have biallelic mutations of LRIG2 (79-81), that encodes a putative plasma membrane protein called leucine-rich-repeats and immunoglobulin-like-domains 2. This protein is thought to mediate growth factor signaling (82), in part by analogy to other better studied LRIG family members (83). Experimental knockdown of the Xenopus hpse 2 homolog in embryos causes disorganized peripheral motor nerves (84) and, in mouse developing urinary tracts, both heparanase 2 and LRIG2 can be immunodetected in pelvic ganglia, the structures that send autonomic nerves into the bladder $(75,81)$. Moreover, both proteins can be detected in nerves growing into normal human fetal bladders (79). Mice that have homozygous mutations for either Hpse $2(75,85)$ or Lrig2 (81) have impaired bladder emptying. Moreover, these mice have abnormal patterns of bladder nerves, with a depletion around the outflow tract, and an overabundance in the body of the bladder (79). Both mutants also show downregulated levels of bladder transcripts encoding neuronal nitric oxide synthase (81), a protein known to mediate bladder outflow dilatation (86). Thus, evidence is accumulating that UFS is a peripheral neuropathy of the urinary bladder, and it is hoped that the definition of aberrant neurobiology will suggest logical therapies for this devastating disease.

\section{CONGENITAL HYDRONEPHROSIS CAUSED BY PRIMARY URETER MALFORMATIONS}

Molecularly upstream of myocardin is another transcription factor called teashirt-3, encoded by TSHZ3 (64, 65, 87). TSHZ3 is normally expressed in mesenchymal cells at the top of the embryonic ureter that are differentiating into smooth muscle cells $(64,88)$. Homozygous mutant Tshz3 mice fail to develop ureteric muscle in this location and, unable to peristalsis in this location, have hydronephrotic functionally obstructed ureters (64). Of note, humans with heterozygous deletions of TSHZ3 can be born with malformed ureters, and these individuals also suffer from an autism-like disorder because the same gene is expressed in, and drives the functional differentiation of, brain cortical neurons (89). Other transcription factors regulate smooth muscle differentiation in the ureter. A preliminary study suggested that TSHZ3 interacts with SOX9 (87) and in humans mutations of the latter gene cause a multiorgan malformation syndrome called campomelic dysplasia (90) featuring sex reversal and hydroureter (91). Similarly, TBX18 is a transcription factor transiently expressed in mesenchymal cells of the embryonic ureter around the urothelium (92). Homozygous mutant Tbx18 mice form fibroblast-like cells rather than normal smooth muscle in this location (92). Humans with heterozygous TBX18 pathogenic variants have been reported (93) who have ureteropelvic junction obstruction and hydronephrosis, a phenotype with a postnatal prevalence of up to $0.3-0.4 \%$ newborns (20-22). Based on cell culture experiments, it is also possible that the same gene is required to differentiation of pacemaker cells in the ureter (94).

\section{POSTERIOR URETHRAL VALVES}

Posterior urethral valves, a disease confined to males, is a common cause of lower urinary tract obstruction detected by antenatal ultrasound screening. When accompanied by oligohydramnios and kidney damage, neonatal survival is compromised and not significantly improved by fetal vesicoamniotic shunting (4). The prevelance of posterior urethral valves has been calculated to be 1 in 7,800 live births (17). Although generally a sporadic disease, families have been reported with more than one sibling affected (95). Moreover, monozygotic vs. dizygotic twin studies are consistent with a genetic component (96). Currently, however, putative genetic bases for posterior urethral valves remain elusive. Two studies $(97,98)$ have reported on a variety of copy number variants in patients with posterior urethral valves but a convincing pattern or stronger evidence of pathogenicity yet to emerge for these. Of note, a preliminary study reported multiple members over three generations affected by anatomical uretral obstruction who carried a heterozygous non-sense mutation of BNC2 (99). This gene codes for basonuclin 2 a zinc finger protein that is expressed in the embryonic urethra (99). Furthermore, experimental downregulation of the homologous gene in zebrafish caused malformation of the distal part of the embryonic urinary tract (99), and mutant Bnc2 mice have malformed urethras (100).

\section{BLADDER EXSTROPHY}

In classic bladder extrophy, the front part of the bladder is open, and this is considered an intermediate severity disorder in the spectrum of mid-line diseases that span epispadias 
and cloacal exstrophy. The prevalence has been measured as 2.1 per 100,000 births, with a positive correlation with maternal age (15). Genetic association studies have implicated variation in the ISL1 locus in classic bladder extrophy, yet pathogenic variants in the ISL1 coding region have not been proven $(101,102)$. Another idea is that the association with the ISL1 locus indicates functional variation of a noncoding genomic region that affects ISL1 expression but this hypothesis has yet to be proven (103). ISL1 is a transcription factor known to be expressed in the region of the forming mouse bladder (102). Mutant Isl1 mice have an epispadiaslike phenotype, and in normal development the encoded transcription factor induces bone morphogenetic factor 4 (BMP4) mediated remodeling of mesenchymal cells (104). Of note, BMP4 is also immunodetected in the walls of human embryonic bladders (105) and other experiments suggest its expression is under the control of sonic hedgehog, a growth factor secreted by embryonic urothelium $(65,105)$. Several studies have sought copy number variants in the bladder extrophyepispadias spectrum, and a small but statistically significant subset of affected individuals have duplication of chromosome 22q11.2 (106-108). The critical region contains numerous genes expressed in the developing kidney and urinary tract including $C R K L$, encoding a transforming protein kinase, that itself has been implicated as causing the kidney malformation found in DiGeorge syndome (109). In this context, however, the gene dosage is reduced (i.e., "haploinsufficiency") rather than amplified and, moreover, the DiGeorge syndrome does not feature bladder extrophy.

\section{CONCLUSIONS AND NOVEL THERAPEUTIC PERSPECTIVES}

As discussed above, the genetic breakthroughs in this field of human disease have come from investigating families with rare congenital urinary tract diseases. Here, studies are indicating that the implicated genes encode smooth muscle, neural or urothelial molecules, or master transcription factors that regulate their expression. To date, however, variants in these same genes do not appear to explain the more common human non-syndromic urinary tract malformations such as primary VUR. Whole exome sequencing, a technology that seeks variants in the protein coding regions of all genes, is being applied to seek likely pathogenic mutation in clinical cohorts, including adult with chronic kidney disease (110) and children born with a range kidney malformations (111). Such research exercises have yielded useful genetic information in $10-14 \%$ of cases tested.

In future, it may be informative to apply these technologies to groups of patients born with the urinary tract malformations described in the current review. It is important to remember, however, that mutations may not be the only explanation for congenital urinary tract malformations. As alluded to in the Introduction, the fetal environment can be modified by alterations in maternal diet or the presence of maternal disease, such as diabetes mellitus (11-14). These non-genetic changes might themselves perturb the normal trajectory of organogenesis. Along the same lines, epigenetic alternations, such as DNA methylation, may profoundly affect expression of renal genes and thus impact on the propensity to disease. For example, such a mechanism has recently been implicated in gene expression of aging human kidneys (112) and there exists preliminary evidence that similar mechanisms may be operative in human renal malformations (113).

At least for the rare syndromes discussed in this review, as the genetics and pathobiology becomes defined, it is possible to begin to envisage smart biological therapies for these diseases to complement conventional pharmacological and surgical clinical interventions. Indeed, gene therapy, for example mediated by viral vectors, may offer promise. In a recent striking breakthrough, babies with spinal muscular atrophy 1 caused by survival motor neuron 1 mutations were intravenously administered adeno-associated virus (AAV) that transduced SMN1, the gene that is at fault in this disease. By 20 months the infants were alive and developing well, whereas untreated individuals would have been expected to have died or alive but severely paralyzed (114). The AAV viral vector used is a non-pathogenic virus that rarely integrates into the host genome, and numerous trials with AAV vectors have been registered for monogenic and other disorders. Of note, specific AAV serotypes can deliver reporter genes into developing mouse renal tracts after maternal, embryonic and neonatal administration; proven targets include kidneys (AAV9), urinary bladders (AAV9) and autonomic and dorsal root and gut ganglia (AAV8 and 9) (115-118). The urinary tract diseases with defined genetic bases, described in this review, meet key criteria for being suitable to be treated with viral gene delivery. Current management for these diseases only attempts to control symptoms, for example with physical bladder drainage, rather than cure the disease process. The diseases are genetically defined, with well-defined links between the normally encoded proteins and disease phenotypes. Moreover, there are phenotypically faithful genetic mouse models on which to test novel biological treatments as first steps to the clinic. The selection of patients who may benefit from novel therapies would, however, have to be highly judicious because the presence of a mutant gene may not in itself be sufficient to generate a clinically significant malformation. This is because the severity of disease in an individual may theoretically be altered by as-yet poorly defined modifying genes, epigenetic changes, and alterations of the fetal environment.

\section{AUTHOR CONTRIBUTIONS}

All authors listed have made a substantial, direct and intellectual contribution to the work, and approved it for publication.

\section{FUNDING}

We acknowledge grant support from: Medical Research Council project grant MR/L002744/1 (AW); Horizon 2020 Marie 
Skłodowska-Curie Actions Initial Training Network (942937) RENALTRACT (AW, FL); Newlife Foundation (AW); Kidney Research UK Non-Clinical Training Fellowship (N.A.R.) and project grant RP_018_20170302 (NR, AW). Histology Core Facility equipment was purchased with grants from the

\section{REFERENCES}

1. Androutsos G. The urology in the anatomical plates of Andreas Vesalius (1514-1564). Prog Urol. (2005) 15:544-50.

2. Kerecuk L, Schreuder MF, Woolf AS. Human renal tract malformations: perspectives for Nephrologists. Nat Clin Pract Nephrol. (2008) 4:312-25. doi: 10.1038/ncpneph0807

3. Capone VP, Morello W, Taroni F, Montini G. Genetics of congenital anomalies of the kidney and urinary tract: the current state of play. Int J Mol Sci. (2017) 18:E796. doi: 10.3390/ijms18040796

4. Morris RK, Malin GL, Quinlan-Jones E, Middleton LJ, Hemming $\mathrm{K}$, Burke D, et al. Percutaneous vesicoamniotic shunting versus conservative management for fetal lower urinary tract obstruction (PLUTO): a randomised trial. Lancet. (2013) 382:1496-506. doi: 10.1016/S0140-6736(13)60992-7

5. Woolf AS, Stuart HM, Newman WG. Genetics of human congenital urinary bladder disease. Pediatr Nephrol. (2014) 29:353-60. doi: 10.1007/s00467-013-2472-1

6. Woolf AS, Davies JA. Cell biology of ureter development. J Am Soc Nephrol. (2013) 24:19-15. doi: 10.1681/ASN.2012020127

7. Woolf AS, Jenkins D. Development of the kidney. In: Heptinstall's Pathology of the Kidney. 7th ed. Jennette JC, Olson JL, Silva FG, D'Agati VD, editors. Philadelphia, PA: Wolters Kluwer (2015). p 67-89.

8. McMahon AP. Development of the mammalian kidney. Curr Top Dev Biol. (2016) 117:31-64. doi: 10.1016/bs.ctdb.2015.10.010

9. Nicolaou N, Renkema KY, Bongers EM, Giles RH, Knoers NV. Genetic, environmental, and epigenetic factors involved in CAKUT. Nat Rev Nephrol. (2015) 11:720-31. doi: 10.1038/nrneph.2015.140

10. van der Ven AT, Vivante A, Hildebrandt F. Novel insights into the pathogenesis of monogenic congenital anomalies of the kidney and urinary tract. J Am Soc Nephrol. (2018) 29:36-50. doi: 10.1681/ASN.20170 50561

11. Woolf AS. Environmental influences on renal tract development: a focus on maternal diet and the glucocorticoid hypothesis. Klin Padiatr. (2011) 223(Suppl. 1):S10-17. doi: 10.1055/s-0030-1255876

12. Lee LM, Leung CY, Tang WW, Choi HL, Leung YC, McCaffery PJ, et al. A paradoxical teratogenic mechanism for retinoic acid. Proc Natl Acad Sci USA. (2012) 109:13668-73. doi: 10.1073/pnas.12008 72109

13. Groen In 't Woud S, Renkema KY, Schreuder MF, Wijers CH, van der Zanden LF, et al. Maternal risk factors involved in specific congenital anomalies of the kidney and urinary tract: a case-control study. Birth Defects Res A Clin Mol Teratol. (2016) 106:596-603. doi: 10.1002/bdra.23500

14. Nasri HZ, Houde Ng K, Westgate MN, Hunt AT, Holmes LB. Malformations among infants of mothers with insulin-dependent diabetes: Is there a recognizable pattern of abnormalities? Birth Defects Res. (2018) 110:108-13. doi: 10.1002/bdr2.1155

15. Siffel C, Correa A, Amar E, Bakker MK, Bermejo-Sánchez E, Bianca S, et al. Bladder exstrophy: an epidemiologic study from the international clearinghouse for birth defects surveillance and research, and an overview of the literature. Am J Med Genet C. (2011) 157C:321-32. doi: 10.1002/ajmg.c.30316

16. Taghavi K, Sharpe C, Stringer MD. Fetal megacystis: a systematic review. J. Pediatr Urol. (2017) 13:7-15. doi: 10.1016/j.jpurol.2016.09.003

17. Thakkar D, Deshpande AV, Kennedy SE. Epidemiology and demography of recently diagnosed cases of posterior urethral valves. Pediatr Res. (2014) 76:560-3. doi: 10.1038/pr.2014.134

18. Williams G, Fletcher JT, Alexander SI, Craig JC. Vesicoureteral reflux. J Am Soc Nephrol. (2008) 19:847-62. doi: 10.1681/ASN.2007020245
University of Manchester Strategic Fund. Human embryonic material was provided by the Joint MRC and Wellcome Trust (MR/R006237/1) Human Developmental Biology Resource (www.hdbr.org). Open Access charges will be requested from the University of Manchester library.

19. Routh JC, Huang L, Retik AB, Nelson CP. Contemporary epidemiology and characterization of newborn males with prune belly syndrome. Urology. (2010) 76:44-8. doi: 10.1016/j.urology.2009.12.072

20. Ek S, Lidefeldt KJ, Varricio L. Fetal hydronephrosis; prevalence, natural history and postnatal consequences in an unselected population. Acta Obstet Gynecol Scand. (2007) 86:463-66. doi: 10.1080/00016340701714802

21. Gunn TR, Mora JD, Pease P. Antenatal diagnosis of urinary tract abnormalities by ultrasonography after 28 weeks' gestation: incidence and outcome. Am J Obstet Gynecol. (1995) 172:479-86. doi: 10.1016/0002-9378(95)90560-X

22. Ismaili K, Hall M, Piepsz A, Wissing KM, Collier F, Schulman C et al. Primary vesicoureteral reflux detected in neonates with a history of fetal renal pelvis dilatation: a prospective clinical and imaging study. J Pediatr. (2006) 148:222-27. doi: 10.1016/j.jpeds.2005.09.037

23. Newman WG, Woolf AS. Urofacial syndrome. In: Adam MP, Ardinger HH, Pagon RA, et al., editors. GeneReviews $($. Seattle, WA: University of Washington; 2013 (updated June 7, 2018).

24. Smellie J, Barratt TM, Chantler C, Gordon I, Prescod NP, et al. Medical versus surgical treatment in children with severe bilateral vesicoureteric reflux and bilateral nephropathy: a randomised trial. Lancet. (2001) 357:1329-33. doi: 10.1016/S0140-6736(00)04520-7

25. Feather SA, Malcolm S, Woolf AS, Wright V, Blaydon D, Reid CJ et al. Primary, nonsyndromic vesicoureteric reflux and its nephropathy is genetically heterogeneous, with a locus on chromosome 1. Am J Hum Genet. (2000) 66:1420-5. doi: 10.1086/302864

26. Sanna-Cherchi S, Reese A, Hensle T, Caridi G, Izzi C, Kim YY, et al. Familial vesicoureteral reflux: testing replication of linkage in seven new multigenerational kindreds. J Am Soc Nephrol. (2005) 16:1781-7. doi: 10.1681/ASN.2004121034

27. Vats KR, Ishwad C, Singla I, Vats A, Ferrell R, Ellis D, et al. A locus for renal malformations including vesico-ureteric reflux on chromosome 13q33-34. J Am Soc Nephrol. (2006) 17:1158-67. doi: 10.1681/ASN.2005040404

28. Weng PL, Sanna-Cherchi S, Hensle T, Shapiro E, Werzberger A, Caridi $\mathrm{G}$, et al. A recessive gene for primary vesicoureteral reflux maps to chromosome 12p11-q13. J Am Soc Nephrol. (2009) 20:1633-40. doi: 10.1681/ASN.2008111199

29. Cordell HJ, Darlay R, Charoen P, Stewart A, Gullett AM, Lambert $\mathrm{HJ}$, et al. Whole-genome linkage and association scan in primary, nonsyndromic vesicoureteric reflux. J Am Soc Nephrol. (2010) 21:113-23. doi: 10.1681/ASN.2009060624

30. Darlow JM, Dobson MG, Darlay R, Molony CM, Hunziker M, Green AJ, et al. A new genome scan for primary nonsyndromic vesicoureteric reflux emphasizes high genetic heterogeneity and shows linkage and association with various genes already implicated in urinary tract development. $\mathrm{Mol}$ Genet Genomic Med. (2014) 2:7-29. doi: 10.1002/mgg3.22

31. Darlow JM, Darlay R, Dobson MG, Stewart A, Charoen P, Southgate J, et al. Genome-wide linkage and association study implicates the $10 \mathrm{q} 26$ region as a major genetic contributor to primary nonsyndromic vesicoureteric reflux. Sci Rep. (2017) 7:14595. doi: 10.1038/s41598-017-15062-9

32. Lu W, van Eerde AM, Fan X, Quintero-Rivera F, Kulkarni S, Ferguson H, et al. Disruption of $\mathrm{ROBO} 2$ is associated with congenital anomalies of kidney and urinary tract and confers risk of vesicoureteric reflux. Am J Hum Genet. (2007) 80:616-32. doi: 10.1086/512735

33. Bertoli-Avella AM, Conte ML, Punzo F, de Graaf BM, Lama G, La Manna A, et al. ROBO2 gene variants are associated with familial vesicoureteral reflux. J Am Soc Nephrol. (2008) 19:825-31. doi: 10.1681/ASN.2007060692

34. Grieshammer U, Le Ma, Plump AS, Wang F, Tessier-Lavigne M, Martin GR. SLIT2-mediated ROBO2 signaling restricts kidney induction to a single site. Dev Cell. (2004) 6:709-17. doi: 10.1016/S1534-5807(04)00108-X 
35. Dobson MG, Darlow JM, Hunziker M, Green AJ, Barton DE, Puri P. Heterozygous non-synonymous $\mathrm{ROBO} 2$ variants are unlikely to be sufficient to cause familial vesicoureteric reflux. Kidney Int. (2013) 84:327-37. doi: 10.1038/ki.2013.100

36. Yang Y, Houle AM, Letendre J, Richter A. RET Gly691Ser mutation is associated with primary vesicoureteral reflux in the FrenchCanadian population from Quebec. Hum Mutat. (2008) 29:695-702. doi: 10.1002/humu.20705

37. Darlow JM, Molloy NH, Green AJ, Puri P, Barton DE. The increased incidence of the RET p.Gly691Ser variant in French-Canadian vesicoureteric reflux patients is not replicated by a larger study in Ireland. Hum Mutat. (2009) 30:E612-17. doi: 10.1002/humu.21009

38. Towers PR, Woolf AS, Hardman P. Glial cell line-derived neurotrophic factor stimulates ureteric bud outgrowth and enhances survival of ureteric bud cells in vitro. Exp Nephrol. (1998) 6:337-51. doi: 10.1159/000020541

39. Kong XT, Deng FM, Hu P, Liang FX, Zhou G, Auerbach AB, et al. Roles of uroplakins in plaque formation, umbrella cell enlargement, and urinary tract diseases. J Cell Biol. (2004) 167:1195-204. doi: 10.1083/jcb.200406025

40. Mitra S, Lukianov S, Ruiz WG, Cianciolo Cosentino C, Sanker S, Traub $\mathrm{LM}$, et al. Requirement for a uroplakin 3a-like protein in the development of zebrafish pronephric tubule epithelial cell function, morphogenesis, and polarity. PLoS ONE. (2012) 7:e41816. doi: 10.1371/journal.pone.0041816

41. Jenkins D, Bitner-Glindzicz M, Malcolm S, Hu CC, Allison J, Winyard PJ, et al. De novo Uroplakin IIIa heterozygous mutations cause human renal adysplasia leading to severe kidney failure. J Am Soc Nephrol. (2005) 16:2141-9. doi: 10.1681/ASN.2004090776

42. Schönfelder EM, Knüppel T, Tasic V, Miljkovic P, Konrad M, Wühl $\mathrm{E}$, et al. Mutations in Uroplakin IIIA are a rare cause of renal hypodysplasia in humans. Am J Kidney Dis. (2006) 47:1004-12. doi: 10.1053/j.ajkd.2006.02.177

43. Palumbo P, Accadia M, Leone MP, Palladino T, Stallone R, Carella M, et al. Clinical and molecular characterization of an emerging chromosome 22q13.31 microdeletion syndromeAm J Med Genet A. (2018) 176:391-8. doi: 10.1002/ajmg.a.38559

44. Jiang S, Gitlin J, Deng F, Liang FX, Atala A, Bauer SB et al. Lack of major involvement of human uroplakin genes in vesicoureteral reflux: implications for disease heterogeneity. Kidney Int. (2004) 66:10-9. doi: 10.1111/j.1523-1755.2004.00703.x

45. Gbadegesin RA, Brophy PD, Adeyemo A, Hall G, Gupta IR, Hains D, et al. TNXB mutations can cause vesicoureteral reflux. J Am Soc Nephrol. (2013) 24:1313-22. doi: 10.1681/ASN.2012121148

46. Elahi S, Homstad A, Vaidya H, Stout J, Hall G, Wu G, et al. Rare variants in tenascin genes in a cohort of children with primary vesicoureteric reflux. Pediatr Nephrol. (2016) 31:247-53. doi: 10.1007/s00467-015-3203-6

47. Schalkwijk J, Zweers MC, Steijlen PM, Dean WB, Taylor G, van Vlijmen IM, et al. A recessive form of the Ehlers-Danlos syndrome caused by tenascin-X deficiency. N Engl J Med. (2001) 345:1167-75. doi: 10.1056/NEJMoa002939

48. Stage KH, Tank ES. Primary congenital bladder diverticula in boys. Urology. (1992) 40:536-8. doi: 10.1016/0090-4295(92)90410-X

49. Favor J, Sandulache R, Neuhäuser-Klaus A, Pretsch W, Chatterjee B, Senft E, et al. The mouse Pax2(1Neu) mutation is identical to a human PAX2 mutation in a family with renal-coloboma syndrome and results in developmental defects of the brain, ear, eye, and kidney. Proc Natl Acad Sci USA. (1996) 93:13870-5.

50. Murawski IJ, Myburgh DB, Favor J, Gupta IR. Vesico-ureteric reflux and urinary tract development in the Pax2 $1 \mathrm{Neu}+/$ - mouse. Am J Physiol Renal Physiol. (2007) 293:F1736-45. doi: 10.1152/ajprenal.00221.2007

51. Sanyanusin P, Schimmenti LA, McNoe LA, Ward TA, Pierpont ME, Sullivan MJ, et al. Mutation of the PAX2 gene in a family with optic nerve colobomas, renal anomalies and vesicoureteral reflux. Nat Genet. (1995) 9:358-64. doi: 10.1038/ng0495-358

52. Weber S, Moriniere V, Knüppel T, Charbit M, Dusek J, Ghiggeri GM, et al. Prevalence of mutations in renal developmental genes in children with renal hypodysplasia: results of the ESCAPE study. J Am Soc Nephrol. (2006) 17:2864-70. doi: 10.1681/ASN.2006030277

53. Choi KL, McNoe LA, French MC, Guilford PJ, Eccles MR. Absence of PAX2 gene mutations in patients with primary familial vesicoureteric reflux. J Med Genet. (1998) 35:338-9. doi: 10.1136/jmg.35.4.338
54. Eagle JF Jr, Barrett GS. Congenital deficiency of abdominal musculature with associated genitourinary abnormalities: a syndrome. Report of 9 cases. Pediatrics. (1950) 6:721-36.

55. Workman SJ, Kogan BA. Fetal bladder histology in posterior urethral valves and the prune belly syndrome. J Urol. (1990) 144:337-39. doi: 10.1016/S0022-5347(17)39448-X

56. Popek EJ, Tyson RW, Miller GJ, Caldwell SA. Prostate development in prune belly syndrome (PBS) and posterior urethral valves (PUV): etiology of PBSlower urinary tract obstruction or primary mesenchymal defect? Pediatr Pathol. (1991) 11:1-29. doi: 10.3109/15513819109064739

57. Weber S, Thiele H, Mir S, Toliat MR, Sozeri B, Reutter H, et al. Muscarinic acetylcholine receptor M3 mutation causes urinary bladder disease and a prune-belly-like syndrome. Am J Hum Genet. (2011) 89:66874. doi: 10.1016/j.ajhg.2011.10.007

58. Matsui M, Motomura D, Karasawa H, Fujikawa T, Jiang J, Komiya Y, et al. Multiple functional defects in peripheral autonomic organs in mice lacking muscarinic acetylcholine receptor gene for the M3 subtype Proc Natl Acad Sci USA. (2000) 97:9579-84. doi: 10.1073/pnas.97.17.9579

59. Pomper JK, Wilhelm H, Tayebati SK, Asmus F, Schüle R, Sievert KD, et al. A novel clinical syndrome revealing a deficiency of the muscarinic $\mathrm{M} 3$ receptor. Neurology. (2011) 76:451-5. doi: 10.1212/WNL.0b013e31820a0a75

60. Richer J, Milewicz DM, Gow R, de Nanassy J, Maharajh G, Miller E, et al. $\mathrm{R} 179 \mathrm{H}$ mutation in ACTA2 expanding the phenotype to include prune-belly sequence and skin manifestations. Am J Med Genet A. (2012) 158A:664-8. doi: 10.1002/ajmg.a.35206

61. Thorson W, Diaz-Horta O, Foster J II, Spiliopoulos M, Quintero R, Farooq A, et al. De novo ACTG2 mutations cause congenital distended bladder, microcolon, and intestinal hypoperistalsis. Hum Genet. (2014) 133:737-42. doi: 10.1007/s00439-013-1406-0

62. Gauthier J, Ouled Amar Bencheikh B, Hamdan FF, Harrison SM, Baker LA, Couture F, et al. A homozygous loss-of-function variant in MYH11 in a case with megacystis-microcolon-intestinal hypoperistalsis syndrome. Eur J Hum Genet. (2015) 23:1266-8. doi: 10.1038/ejhg.2014.256

63. Halim D, Brosens E, Muller F, Wangler MF, Beaudet AL, Lupski JR, et al. Loss-of-function variants in MYLK cause recessive megacystis microcolon intestinal hypoperistalsis syndrome. Am J Hum Genet. (2017) 101:123-9. doi: 10.1016/j.ajhg.2017.05.011

64. Caubit X, Lye CM, Martin E, Core N, Long DA, Vola C, et al. Teashirt 3 is necessary for ureteral smooth muscle differentiation downstream of SHH and BMP4. Development. (2008) 135:3301-10. doi: 10.1242/dev. 022442

65. Lye CM, Fasano L, Woolf AS. Ureter myogenesis: putting Teashirt into context. J Am Soc Nephrol. (2010) 21:24-30. doi: 10.1681/ASN.2008111206

66. Hirai H, Yang B, Garcia-Barrio MT, Rom O, Ma PX, Zhang J, et al. Direct reprogramming of fibroblasts into smooth muscle-like cells with defined transcription factors- brief report. Arterioscler Thromb Vasc Biol. (2018) 38:2191-7. doi: 10.1161/ATVBAHA.118.310870

67. Boghossian NS, Sicko RJ, Giannakou A, Dimopoulos A, Caggana M, Tsai MY, et al. Rare copy number variants identified in prune belly syndrome. Eur J Med Genet. (2018) 61:145-51. doi: 10.1016/j.ejmg.2017.11.008

68. Haeri S Devers PL, Kaiser-Rogers KA, Moylan VJ Jr, Torchia BS, Horton AL, Wolfe HM, Aylsworth AS. Deletion of hepatocyte nuclear factor-1-beta in an infant with prune belly syndrome. Am J Perinatol. (2010) 27:559-63. doi: 10.1055/s-0030-1248943

69. Kolatsi-Joannou M, Bingham C, Ellard S, Bulman MP, Allen LIS, Hattersley AT, et al. Hepatocyte nuclear factor $1 \beta$ : a new kindred with renal cysts and diabetes, and gene expression in normal human development. J Am Soc Nephrol. (2001) 12:2175-80.

70. Adalat S, Woolf AS, Johnstone KA, Wirsing A, Harries LW, Long DA, et al. Hepatocyte Nuclear Factor $1 B$ mutations associate with hypomagnesemia and renal magnesium wasting. J Am Soc Nephrol. (2009) 20:1123-31. doi: 10.1681/ASN.2008060633

71. Granberg CF, Harrison SM, Dajusta D, Zhang S, Hajarnis S, Igarashi P, et al. Genetic basis of prune belly syndrome: screening for HNF1 $\beta$ gene. J Urol. (2012) 187:272-8. doi: 10.1016/j.juro.2011.09.036

72. Ochoa B. Can a congenital dysfunctional bladder be diagnosed from a smile? The Ochoa syndrome updated. Pediatr Nephrol. (2004) 19:6-12. doi: 10.1007/s00467-003-1291-1 
73. Daly SB, Urquhart JE, Hilton E, McKenzie EA, Kammerer RA, Lewis M, et al. Mutations in HPSE2 cause urofacial syndrome. Am J Hum Genet. (2010) 11:963-9. doi: 10.1016/j.ajhg.2010.07.010

74. Pang J, Zhang S, Yang P, Hawkins-Lee B, Zhong J, Zhang Y, et al. Loss-of-function mutations in HPSE2 cause the autosomal recessive urofacial syndrome. Am J Hum Genet. (2010) 86:957-62. doi: 10.1016/j.ajhg.2010.06.014

75. Stuart HM, Roberts NA, Hilton EN, McKenzie EA, Daly SB, Hadfield KD, et al. Urinary tract effects of HPSE2 mutations. J Am Soc Nephrol. (2015) 26:797-804. doi: 10.1681/ASN.2013090961

76. Mahmood S, Beetz C, Tahir MM, Imran M, Mumtaz R, Bassmann I, et al. First HPSE2 missense mutation in urofacial syndrome. Clin Genet. (2012) 81:88-92. doi: 10.1111/j.1399-0004.2011.01649.x

77. Vivante A, Hwang DY, Kohl S, Chen J, Shril S, Schulz J, et al. Exome sequencing discerns syndromes in patients from consanguineous families with congenital anomalies of the Kidneys and urinary tract. J Am Soc Nephrol. (2017) 28:69-75. doi: 10.1681/ASN.2015080962

78. Levy-Adam F, Feld S, Cohen-Kaplan V, Shteingauz A, Gross M, Arvatz G, Naroditsky I, Ilan N, Doweck I, Vlodavsky I. Heparanase 2 interacts with heparan sulfate with high affinity and inhibits heparanase activity. J Biol Chem. (2010) 285:28010-9. doi: 10.1074/jbc.M110.116384

79. Stuart HM, Roberts NA, Bergu B, Daly SB, Urquhart JE, Bhaskar S, et al. LRIG2 mutations cause urofacial syndrome. Am J Hum Genet. (2013) 92:259-64. doi: 10.1016/j.ajhg.2012.12.002

80. Fadda A, Butt F, Tomei S, Deola S, Lo B, Robay A, et al. Two hits in one: whole genome sequencing unveils LIG4 syndrome and urofacial syndrome in a case report of a child with complex phenotype. BMC Med Genet. (2016) 17:84. doi: 10.1186/s12881-016-0346-7

81. Roberts NA, Hilton EN, Lopes FM, Randles MJ, Sigh S, Gardiner NJ et al. Lrig2 and Hpse2, mutated in urofacial syndrome, pattern nerves in the urinary bladder. Kidney Int. (2019). doi: 10.1016/j.kint.2018.11.040. [Epub ahead of print].

82. Xiao Q, Dong M, Cheng F, Mao F, Zong W, Wu K, et al. LRIG2 promotes the proliferation and cell cycle progression of glioblastoma cells in vitro and in vivo through enhancing PDGFR $\beta$ signaling. Int J Oncol. (2018) 53:1069-82. doi: $10.3892 /$ ijo.2018.4482

83. Simion C, Cedano-Prieto ME, Sweeney C. The LRIG family: enigmatic regulators of growth factor receptor signaling. Endocr Relat Cancer. (2014) 21:R431-43. doi: 10.1530/ERC-14-0179

84. Roberts NA, Woolf AS, Stuart HM, Thuret R, McKenzie EA, Newman WG, et al. Heparanase 2, mutated in urofacial syndrome, mediates peripheral neural development in Xenopus. Hum Mol Genet. (2014) 23:4302-14. doi: 10.1093/hmg/ddu147

85. Guo C, Kaneko S, Sun Y, Huang Y, Vlodavsky I, Li X, et al. A mouse model of urofacial syndrome with dysfunctional urination. Hum Mol Genet. (2015) 24:1991-9. doi: 10.1093/hmg/ddu613

86. Burnett AL, Calvin DC, Chamness SL, Liu JX, Nelson RJ, Klein SL, et al. Urinary bladder-urethral sphincter dysfunction in mice with targeted disruption of neuronal nitric oxide synthase models idiopathic voiding disorders in humans. Nat Med. (1997) 3:571-4. doi: 10.1038/nm0597-571

87. Martin E, Caubit X, Airik R, Vola C, Fatmi A, Kispert A, et al. TSHZ3 and SOX9 regulate the timing of smooth muscle cell differentiation in the ureter by reducing myocardin activity. PLoS ONE. (2013) 8:e63721. doi: 10.1371/journal.pone.0063721

88. Jenkins D, Caubit X, Dimovski A, Matevska N, Lye CM, Cabuk F, et al. Analysis of TSHZ2 and TSHZ3 genes in congenital pelviureteric junction obstruction. Nephrol Dial Transplant. (2010) 25:54-60. doi: $10.1093 / \mathrm{ndt} / \mathrm{gfp} 453$

89. Caubit X, Gubellini P, Andrieux J, Roubertoux P, Metwaly M, Jacq B, et al. TSHZ3 deletion causes an autism syndrome and defects in cortical projection neurons. Nature Genet. (2016) 48:1359-69. doi: 10.1038/ng.3681

90. Südbeck P, Schmitz ML, Baeuerle PA, Scherer G. Sex reversal by loss of the C-terminal transactivation domain of human SOX9. Nat Genet. (1996) 13:230-2.

91. Houston CS, Opitz JM, Spranger JW, Macpherson RI, Reed MH, Gilbert EF, et al. The campomelic syndrome: review, report of 17 cases, and follow-up on the currently 17-year-old boy first reported by Maroteaux et al in 1971 . Am J Med Genet. (1983) 15:3-28. doi: 10.1002/ajmg.1320150103
92. Bohnenpoll T, Bettenhausen E, Weiss AC, Foik AB, Trowe MO, Blank P, et al. Tbx18 expression demarcates multipotent precursor populations in the developing urogenital system but is exclusively required within the ureteric mesenchymal lineage to suppress a renal stromal fate. Dev Biol. (2013) 380:25-36. doi: 10.1016/j.ydbio.2013.04.036

93. Vivante A, Kleppa MJ, Schulz J, Kohl S, Sharma A, Chen J, et al. Mutations in TBX18 cause dominant urinary tract malformations via transcriptional dysregulation of ureter development. Am J Hum Genet. (2015) 97:291-301. doi: 10.1016/j.ajhg.2015.07.001

94. Xiao H, Yang YJ, Lin YZ, Peng S, Lin S, Song ZY. Transcription factor Tbx18 induces the differentiation of $\mathrm{c}$-kit ${ }^{+}$canine mesenchymal stem cells (cMSCs) into SAN-like pacemaker cells in a co-culture model in vitro. Am J Transl Res. (2018) 10:2511-28.

95. . Chiaramonte C, Bommarito D, Zambaiti E, Antona V, Li Voti G. Genetic basis of posterior urethral valves inheritance. Urology. (2016) 95:175-9. doi: 10.1016/j.urology.2016.05.043

96. Frese S, Weigert A, Hoppe B, Feldkötter M, Ludwig M, Weber S, et al. A classic twin study of lower urinary tract obstruction: report of 3 cases and literature review. Low Urin Tract Symptoms. (2018). doi: 10.1111/luts.12222. [Epub ahead of print].

97. Boghossian NS, Sicko RJ, Kay DM, Rigler SL, Caggana M, Tsai MY, et al. Rare copy number variants implicated in posterior urethral valves. Am J Med Genet A. (2016) 170:622-33. doi: 10.1002/ajmg.a.37493

98. Faure A, Bouty A, Caruana G, Williams L, Burgess T, Wong MN, et al. DNA copy number variants: a potentially useful predictor of early onset renal failure in boys with posterior urethral valves. J Pediatr Urol. (2016) 12:227.e1-7. doi: 10.1016/j.jpurol.2016.02.020

99. Kolvenbach CM, Frese SK, Dworschak GC, Japp A, Schmidt JM, Zaniew M, et al. Mutations in BNC2 lead to autosomal-dominant lower urinary tract obstruction (LUTO). Pediatr Nephrol. (2018) 33:1809-10. Available online at: https://espn2018.org/abstracts/abstract.php?bid=146

100. Bhoj EJ, Ramos P, Baker LA, Garg V, Cost N, Nordenskjöld A, et al. Human balanced translocation and mouse gene inactivation implicate Basonuclin 2 in distal urethral development. Eur J Hum Genet. (2011) 19:540-6. doi: 10.1038/ejhg.2010.245

101. Zhang R, Knapp M, Suzuki K, Kajioka D, Schmidt JM, Winkler J, et al. ISL1 is a major susceptibility gene for classic bladder exstrophy and a regulator of urinary tract development. Sci Rep. (2017) 7:42170. doi: 10.1038/srep42170

102. Arkani S, Cao J, Lundin J, Nilsson D, Källman T, Barker G, et al. Evaluation of the ISL1 gene in the pathogenesis of bladder exstrophy in a Swedish cohort. Hum Genome Var. (2018) 5:18009. doi: 10.1038/hgv.2018.9

103. Zhang R, Knapp M, Kause F, Reutter H, Ludwig M. Role of the LF-SINEderived distal ISL1 enhancer in patients with classic bladder exstrophy. $J$ Pediatr Genet. (2017) 6:169-73. doi: 10.1055/s-0037-1602387

104. Ching ST, Infante CR, Du W, Sharir A, Park S, Menke DB, et al. Isl1 mediates mesenchymal expansion in the developing external genitalia via regulation of Bmp4, Fgf10 and Wnt5a. Hum Mol Genet. (2018) 27:107-19. doi: $10.1093 / \mathrm{hmg} / \mathrm{ddx} 388$

105. Jenkins D, Winyard PJD, Woolf AS. Immunohistochemical analysis of sonic hedgehog signalling in normal human urinary tract development. J Anat. (2007) 211:620-9. doi: 10.1111/j.1469-7580.2007.00808.x

106. Draaken M, Reutter H, Schramm C, Bartels E, Boemers TM, Ebert $\mathrm{AK}$, et al. Microduplications at $22 \mathrm{q} 11.21$ are associated with nonsyndromic classic bladder exstrophy. Eur J Med Genet. (2010) 53:55-60. doi: 10.1016/j.ejmg.2009.12.005

107. Draaken M, Baudisch F, Timmermann B, Kuhl H, Kerick M, Proske J, et al. Classic bladder exstrophy: Frequent 22q11.21 duplications and definition of a $414 \mathrm{~kb}$ phenocritical region. Birth Defects Res A Clin Mol Teratol. (2014) 100:512-7. doi: 10.1002/bdra.23249

108. Beaman GM, Woolf AS, Cervellione RM, Keene D, Mushtaq I, Urquhart JE, et al. 22q11.2 duplications in a UK cohort with bladder exstrophy-epispadias complex. Am J Med Genet A. (2019) 179:404-9. doi: 10.1002/ajmg.a.61032

109. Lopez-Rivera E, Liu YP, Verbitsky M, Anderson BR, Capone VP, Otto EA, et al. Genetic drivers of kidney defects in the DiGeorge syndrome. N Engl J Med. (2017) 376:742-54. doi: 10.1056/NEJMoa1609009

110. Groopman EE, Marasa M, Cameron-Christie S, Petrovski S, Aggarwal VS, Milo-Rasouly $\mathrm{H}$, et al. Diagnostic utility of exome sequencing for kidney disease. N Engl J Med. (2019) 380:142-51. doi: 10.1056/NEJMoa1806891 
111. van der Ven AT, Connaughton DM, Ityel H, Mann N, Nakayama M, Chen J, et al. Whole-exome sequencing identifies causative mutations in families with congenital anomalies of the kidney and urinary tract. J Am Soc Nephrol. (2018) 29:2348-61. doi: 10.1681/ASN.2017121265

112. Rowland J, Akbarov A, Eales J, Xu X, Dormer JP, Guo H, Denniff $\mathrm{M}$, et al. Uncovering genetic mechanisms of kidney aging through transcriptomics, genomics, and epigenomics. Kidney Int. (2019) 95:624-35. doi: 10.1016/j.kint.2018.10.029

113. Jin M, Zhu S, Hu P, Liu D, Li Q, Li Z et al. Genomic and epigenomic analyses of monozygotic twins discordant for congenital renal agenesis. Am J Kidney Dis. (2014) 64:119-22. doi: 10.1053/j.ajkd.2014.01.423

114. Mendell JR, Al-Zaidy S, Shell R, Arnold WD, Rodino-Klapac LR, Prior TW, et al. single-dose gene-replacement therapy for spinal muscular atrophy. $N$ Engl J Med. (2007) 377:1713-2. doi: 10.1056/NEJMoa1706198

115. Picconi JL, Muff-Luett MA, Wu D, Bunchman E, Schaefer F, Brophy PD. Kidney-specific expression of GFP by in-utero delivery of pseudotyped adeno-associated virus 9. Mol Ther Methods Clin Dev. (2015) 1:14014. doi: $10.1038 / \mathrm{mtm} .2014 .14$

116. Karda R, Buckley SM, Mattar CN, Ng J, Massaro G, Hughes MP, Kurian MA, et al. Perinatal systemic gene delivery using adeno-associated viral vectors. Front Mol Neurosci. (2014) 7:89. doi: 10.3389/fnmol.2014.00089
117. Mattar CN, Wong AM, Hoefer K, Alonso-Ferrero ME, Buckley SM, Howe SJ, et al. Systemic gene delivery following intravenous administration of AAV9 to fetal and neonatal mice and late-gestation nonhuman primates. FASEB J. (2015) 29:3876-88. doi: 10.1096/fj.14-269092

118. Buckinx R, Van Remoortel S, Gijsbers R, Waddington SN, Timmermans JP. Proof-of-concept: neonatal intravenous injection of adeno-associated virus vectors results in successful transduction of myenteric and submucosal neurons in the mouse small and large intestine. Neurogastroenterol Motil. (2016) 28:299-305. doi: 10.1111/nmo.12724

Conflict of Interest Statement: The authors declare that the research was conducted in the absence of any commercial or financial relationships that could be construed as a potential conflict of interest.

Copyright (c) 2019 Woolf, Lopes, Ranjzad and Roberts. This is an open-access article distributed under the terms of the Creative Commons Attribution License (CC BY). The use, distribution or reproduction in other forums is permitted, provided the original author(s) and the copyright owner(s) are credited and that the original publication in this journal is cited, in accordance with accepted academic practice. No use, distribution or reproduction is permitted which does not comply with these terms. 